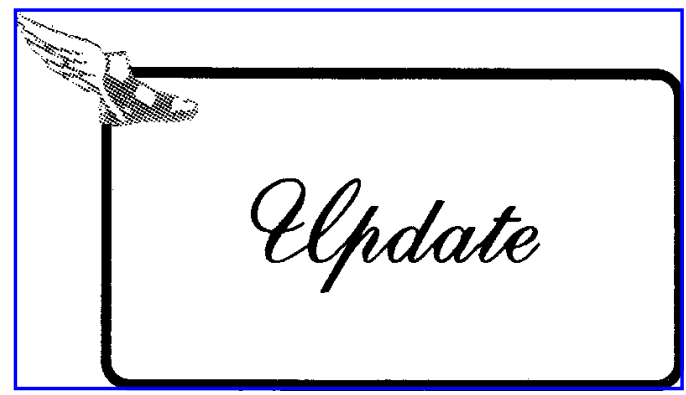

\title{
Radionuclide Imaging of Tumor Angiogenesis
}

\author{
Ingrid Dijkgraaf and Otto C. Boerman
}

\section{Summation}

Angiogenesis is a multistep process regulated by pro- and antiangiogenic factors. In order to grow and metastasize, tumors need a constant supply of oxygen and nutrients. For growth beyond 1-2 $\mathrm{mm}$ in size, tumors are dependent on angiogenesis. Inhibition of angiogenesis is a new cancer treatment strategy that is now widely investigated clinically. Researchers have begun to search for objective measures that indicate pharmacologic responses to antiangiogenic drugs. Therefore, there is a great interest in techniques to visualize angiogenesis in growing tumors noninvasively. Several markers have been described that are preferentially expressed on newly formed blood vessels in tumors $\left(\alpha_{\mathrm{v}} \beta_{3}\right.$ integrin, vascular endothelial growth factor, and its receptor, prostatespecific membrane antigen) and in the extracellular matrix surrounding newly formed blood vessels (extra domain B of fibronectin, Tenascin-C, matrix metalloproteinases, and Robo-4). Several ligands targeting these markers have been tested as a radiotracer for imaging angiogenesis in tumors. The potential of some of these tracers, such as radiolabeled cyclic RGD peptides and radiolabeled anti-PSMA antibodies, has already been tested in cancer patients, while for markers such as Robo-4, the ligand has not yet been identified. In this review, an overview on the currently used nuclear imaging probes for noninvasive visualization of tumor angiogenesis is given.

Key words: angiogenesis, $\alpha_{v} \beta_{3}, \alpha_{5} \beta_{1}$, VEGF, PMSA, ECM, Magic roundabout

\section{Introduction}

A ngiogenesis, the formation of new blood vessels from existing ones, is an essential process if solid tumors are to grow beyond $2-3 \mathrm{~mm}^{3}$, since diffusion is no longer sufficient to supply the tissue with oxygen and nutrients. ${ }^{1}$ Tumorinduced angiogenesis is a complex, multistep process that follows a characteristic cascade of events mediated and controlled by growth factors, cellular receptors, and adhesion molecules. $^{2-4}$ In this process, five phases can be distinguished: 1) endothelial cell activation, 2) basement membrane degradation, 3) endothelial cell migration, 4) vessel formation, and 5) angiogenic remodeling. ${ }^{5}$

The activation of preexisting quiescent vessels can be triggered by hypoxia. Hypoxia induces the expression of hypoxia-inducible factor (HIF), which binds to the hypoxic response element. As a result, the expression of hypoxiainducible genes, such as vascular endothelial growth factor
(VEGF), carbonic anhydrase IX (CAIX), platelet-derived growth factor (PDGF), and transforming growth factor- $\alpha$ (TGF- $\alpha$ ), is induced. ${ }^{6}$

Activated endothelial cells express the dimeric transmembrane integrin, $\alpha_{v} \beta_{3}$, which interacts with extracellular matrix proteins (e.g., vitronectin, tenascin, fibronectin, and so forth) and regulates migration of the endothelial cell through the extracellular matrix during vessel formation. ${ }^{7,8}$ The activated endothelial cells synthesize proteolytic enzymes, such as matrix metalloproteinases (MMPs), used to degrade the basement membrane and the extracellular matrix. ${ }^{9}$ Initially, endothelial cells assemble as solid cords. Subsequently, the inner layer of endothelial cells undergoes apoptosis, leading to the formation of the vessel lumen. Finally, this primary, immature vasculature undergoes extensive remodeling, during which the vessels are stabilized by pericytes and smooth muscle cells. This step is often incomplete in tumors, resulting in the characteristic, increased permeability of tumor vessels.

Department of Nuclear Medicine, Radboud University Nijmegen Medical Center, Nijmegen, The Netherlands.

Address correspondence to: Ingrid Dijkgraaf; Department of Nuclear Medicine, Radboud University Nijmegen Medical Center, P.O. Box 9101, 6500 HB Nijmegen, The Netherlands

E-mail: I.Dijkgraaf@nucmed.umcn.nl 
Based on a balance between pro- and antiangiogenic factors, a tumor can stay dormant for a very long time until the so-called "angiogenic switch" occurs. In most tissues, tumors can only grow to a life-threatening size if the tumor is able to trigger angiogenesis. In tissues with high vessel densities (e.g., liver, brain, and so forth), tumors may also progress via angiogenesis-independent co-option of the preexistent vasculature. $^{10}$

In summary, tumor-induced angiogenesis is a multistep process and a key feature of a tumor lesion that has major impact on the biologic behavior of the lesion. Inhibition of angiogenesis is a new cancer treatment strategy that is now widely investigated clinically. Researchers have begun to search for objective measures that indicate pharmacologic responses to antiangiogenic drugs. Therefore, there is a great interest in techniques to visualize angiogenesis in growing tumors noninvasively. During the past decade, several markers of angiogenesis have been identified and specific tracers targeting these markers have been developed. In this review, an overview on the currently used nuclear imaging probes for noninvasive visualization of tumor angiogenesis is given.

\section{$\alpha_{v} \beta_{3}$ Integrin Receptor}

The $\alpha_{\mathrm{v}} \beta_{3}$ integrin, also referred to as the vitronectin receptor, belongs to the integrin receptors. Integrins are a family of heterodimeric transmembrane glycoproteins that function in cellular adhesion, migration, and signal transduction. The term "integrin" was derived from the ability of these proteins to link the extracellular matrix (ECM) proteins with the intracellular cytoskeleton. ${ }^{11}$ Each member of this family consists of two noncovalently bound transmembrane polypeptide subunits, alpha and beta. Integrins have a large extracellular domain, which binds extracellular ligands, a transmembrane domain, and a relatively small intracellular domain responsible for interaction with the cytoskeleton and intracellular signaling pathways. To date, 18 alpha- and 8 beta-subunits have been identified, which associate selectively to form at least 24 different integrins. The unique combinations of alpha- and beta-subunits determine which ECM ligands are recognized by a cell. Binding of ECM ligands to integrins triggers interactions between several signaling molecules in close vicinity to the extracellular and cytoplasmic regions of the integrin receptor. ${ }^{12,13}$ Integrinmediated cell adhesion may affect the cell-cycle kinetics or may cause anchorage-dependent cell death or anoikis. ${ }^{14,15}$

The alpha-v-subunit can associate with various integrin beta-subunits. At present, there are at least three distinct $\beta$-subunits known, which associate with the $\alpha_{\mathrm{v}}$-subunit, namely, $\beta_{1}, \beta_{3}$, and $\beta_{5}$. Integrin $\alpha_{v} \beta_{3}$ is expressed on a variety of cell types, including osteoclasts, vascular smooth muscle cells, and endothelial cells. In addition, $\alpha_{v} \beta_{3}$ integrin is expressed on the cell membrane of various tumor cell types, such as ovarian cancer, neuroblastoma, breast cancer, melanoma, and others. Further, integrin $\alpha_{v} \beta_{3}$ is minimally expressed on normal quiescent endothelial cells, but significantly upregulated on activated endothelial cells during angiogenesis. ${ }^{16} \alpha_{v} \beta_{3}$ integrin expressed on endothelial cells modulate cell migration and survival during angiogenesis, whereas $\alpha_{v} \beta_{3}$ integrin expressed on carcinoma cells potentiate metastasis by facilitating invasion and movement across blood vessels.
Integrin $\alpha_{\mathrm{v}} \beta_{3}$ binds extracellular matrix proteins (e.g., vitronectin, fibrinogen, laminin, and collagen) through exposed tripeptide arginine-glycine-aspartic acid (RGD) amino-acid moieties. ${ }^{17}$ Several research groups have investigated the potential of RGD-containing peptides to target $\alpha_{v} \beta_{3}$ expressed in tumors with radionuclides. It was found that the cyclic pentapeptide, cyclo(Arg-Gly-Asp-D-Phe-Val), having an $\mathrm{IC}_{50}$ value in the lower nanomolar range, was a 100 -fold better inhibitor of cell adhesion to vitronectin, compared to the linear variant. ${ }^{18,19}$ It was found that besides the essential RGD sequence, a hydrophobic amino acid in position 4 increases the affinity for $\alpha_{\mathrm{v}} \beta_{3}{ }^{20}$ Based on this finding, Haubner et al. designed five peptides that could be radioiodinated by introducing a tyrosine residue. Two of these peptides, cyclo(Arg-Gly-Asp-D-Tyr-Val) and cyclo(ArgGly-Asp-D-Phe-Tyr) (designated as P1 and P4, respectively), were studied in vivo. ${ }^{21}$ The biodistribution of the radioiodinated peptides was studied in nude mice with various subcutaneous (s.c.) human tumors (M21 melanoma, MaCaF mammary carcinoma, and osteocarcoma). The peptides rapidly cleared from the blood; blood levels were lower than $1 \% \mathrm{ID} / \mathrm{g}$ (percent injected dose per $\mathrm{g}$ ) as early as 10 minutes postinjection (p.i.). In the M21 melanoma model, the tumor uptake peaked at 10 minutes p.i. $(1.12 \pm 0.98 \% \mathrm{ID} / \mathrm{g})$ and decreased to $0.12 \pm 0.04 \% \mathrm{ID} / \mathrm{g}$ at 2 hours p.i. However, both peptides cleared via the hepatobiliary route and revealed relatively high hepatic uptake, especially at early time points ( $\sim 5 \% \mathrm{ID} / \mathrm{g}, 1$ hour p.i.). Therefore, the pharmacokinetics of this first-generation radiohalogenated RGD peptides were improved by conjugating them with sugar amino acids. A glucose-based sugar amino acid (SAA1) was conjugated to the epsilon-amino function of lysine in the pentapeptide. Compared to the noncarbohydrated radioiodinated $\mathrm{P} 4$, the resulting iodine-labeled glucopeptide, 3-[*I]iodo-D-Tyr4cyclo(Arg-Gly-Asp-D-Tyr-Lys (SAA1)) (*I-Gluco-RGD) showed reduced activity accumulation in the liver, an initially increased activity concentration in the blood, and an increased uptake and retention in the tumor. ${ }^{22}$ Based on these data, a galactose-based sugar amino acid (SAA2) was conjugated with cyclo(Arg-Gly-Asp-D-Phe-Lys), allowing prosthetic group labeling. ${ }^{22,23}$ Due to the low lipophilicity of the small propionyl moiety, 4-nitrophenyl-2-[ $\left.{ }^{18} \mathrm{~F}\right]$ fluoropropoinate $\left(\left[{ }^{18} \mathrm{~F}\right] \mathrm{NFP}\right)$ was used for ${ }^{18} \mathrm{~F}$-labeling. The resulting $\left[{ }^{18} \mathrm{~F}\right]$ Galacto-RGD was the first radiotracer applied in patients.

The conjugation of the DTPA-moiety in the pentapeptide, cyclo(Arg-Gly-Asp-D-Tyr-Lys), via the epsilon group of the lysine residue also made the peptide more hydrophilic and facilitated renal clearance, in contrast to the non-DTPAconjugated radioiodinated peptide, which is cleared predominantly via the hepatic route. ${ }^{24}$

The hydrophilicity of peptides can also be enhanced by linking them to polyethylene glycol (PEG) chains, an approach called PEGylation. Chen et al. coupled PEG-moieties to RGD-containing peptides. Radioiodinated, ${ }^{18} \mathrm{~F}-$, and ${ }^{64} \mathrm{Cu}-$ labeled derivatives were studied and demonstrated different effects of PEGylation on the pharmacokinetics, tumor uptake, and retention of the RGD peptides. This could be due to the nature of the lead structure and the size of the PEG-moiety. For example, ${ }^{125}$ I-RGD-mPEG [mPEG molecular weight $(\mathrm{MW})=2000$ ] demonstrated higher activity concentration in liver and intestines, compared to ${ }^{125}$ I-RGD. In addition, the PEGylated analog showed faster blood clearance, lower 
tumor uptake, but improved tumor retention, compared to ${ }^{125}$ I-RGD. ${ }^{25}$ In contrast, the PEGylated RGD peptide, ${ }^{64} \mathrm{Cu}$ DOTA-PEG-RGD (PEG MW = 3400), showed lower uptake in liver and intestine with no effect on tumor uptake and retention, compared to ${ }^{64} \mathrm{Cu}$-DOTA-RGD. ${ }^{26}$ A direct comparison in mice with s.c. U87MG glioblastoma demonstrated that $\left[{ }^{18}\right.$ F]FB-PEG-RGD (PEG MW=3400) had significantly improved tumor retention relative to $\left[{ }^{18} \mathrm{~F}\right] \mathrm{FB}-\mathrm{RGD}$ without compromising hepatic and renal clearance of activity. ${ }^{27}$

Recently, a ${ }^{99} \mathrm{~m}$ Tc-labeled RGD-containing peptide (NC100692) was evaluated in ischemic models and showed high uptake in areas of neovascularization with $\alpha_{\mathrm{v}} \beta_{3}$ integrin overexpression. $^{28}$ In these models, it was shown that NC100692 bonds to $\alpha_{\mathrm{v}} \beta_{3}$-expressing endothelial cells in the regions of angiogenesis. ${ }^{29}$

\section{Clinical studies}

As described above, $\left[{ }^{18} \mathrm{~F}\right]$ Galacto-RGD was the first radiotracer applied in patients and could successfully image $\alpha_{\mathrm{v}} \beta_{3}$ expression in human tumors with good tumor-tobackground ratios. ${ }^{30}$ Further biodistribution and dosimetry studies confirmed rapid clearance of $\left[{ }^{18} \mathrm{~F}\right] \mathrm{Galacto}-\mathrm{RGD}$ from the blood pool and, primarily, renal excretion. ${ }^{31-33}$ It has been shown that molecular imaging of $\alpha_{\mathrm{v}} \beta_{3}$ expression, with $\left[{ }^{18} \mathrm{~F}\right]$ Galacto-RGD in humans correlated with $\alpha_{\mathrm{v}} \beta_{3}$ expression, as determined by immunohistochemistry. ${ }^{34}$ In another study, the tracer uptake of $\left[{ }^{18} \mathrm{~F}\right] \mathrm{FDG}$ and $\left[{ }^{18} \mathrm{~F}\right]$ Galacto-RGD in patients with non-small-cell lung cancer (NSCLC; $n=10$ ) and various other tumors $(n=8)$ was compared (Fig. 1$)$, indicating that $\left[{ }^{18} \mathrm{~F}\right] \mathrm{FDG}$ uptake in tumor lesions did not correlate with $\left[{ }^{18} \mathrm{~F}\right] \mathrm{Galacto}-\mathrm{RGD}$ uptake. These results showed that $\alpha_{\mathrm{v}} \beta_{3}$ expression and glucose metabolism are not closely correlated in tumor lesions, and that, consequently, $\left[{ }^{18} \mathrm{~F}\right] \mathrm{FDG}$ cannot provide similar information as $\left[{ }^{18} \mathrm{~F}\right]$ Galacto-RGD. ${ }^{35}$

The second radiotracer that was applied in patients was ${ }^{99 \mathrm{~m}}$ Tc-NC100692. A clinical study was performed to provide an initial indication of the efficacy and safety of imaging malignant breast tumors. ${ }^{36}$ Nineteen (19) of 22 tumors were detected with this radiotracer. In an additional study,
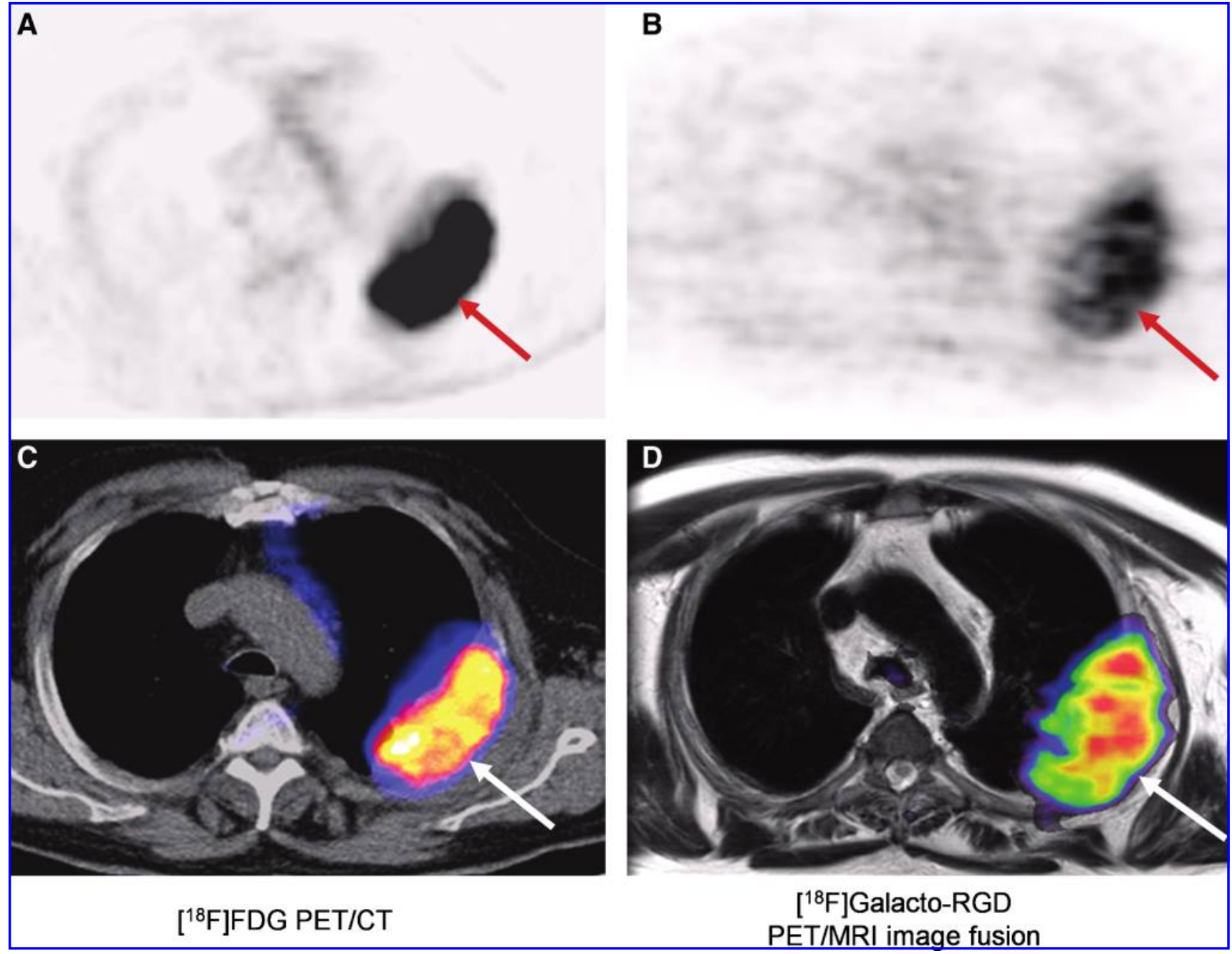

FIG. 1. $\left[{ }^{18} \mathrm{~F}\right]$ FDG-PET of a patient with non-small-cell lung cancer (NSCLC) showed intense tracer uptake in the lesion (A). PET imaging of $\alpha_{\mathrm{v}} \beta_{3}$ integrin expression with $\left[{ }^{18} \mathrm{~F}\right]$ Galacto-RGD showed heterogeneous tracer uptake in the lesion, with a different pattern, compared to the $\left[{ }^{18} \mathrm{~F}\right] \mathrm{FDG}-\mathrm{PET}(\mathbf{B})$. PET/CT (C) and PET/MRI (T2w) image fusion (D) are useful for a good correlation of anatomic and biologic information. FDG, Fluorodeoxyglucose; PET, positron emission tomography; CT, computed tomography; MRI, magnetic resonance imaging. 
integrin scintimammography with ${ }^{99 \mathrm{~m}} \mathrm{Tc}-\mathrm{NC} 100692$, using a dedicated $\gamma$-camera, was performed to investigate the ability to detect malignant breast cancer lesions. ${ }^{37}$ All patients were known to have lesions highly suspicious of malignancy. Dedicated integrin scintimammography (DISM) detected malignant lesions in 7 of 8 patients with focal uptake in all but 2 tumor lesions.

\section{Multimeric RGD peptides}

To improve the efficiency of tumor targeting and to obtain better in vivo imaging properties, multimeric RGD peptides were synthesized and characterized. The first cyclic RGD multimers that were developed were $E[c(R G D f K)]_{2}$-based dimers (Fig. 2). ${ }^{38-44}$ Subsequently, the Stanford group reported the use of $\mathrm{E}[\mathrm{c}(\mathrm{RGDyK})]_{2}$-based dimers labeled with ${ }^{64} \mathrm{Cu}$ or ${ }^{18} \mathrm{~F}$ for positron emission tomography (PET) imaging. ${ }^{45}$ The dimeric RGD peptide, $\mathrm{E}(\mathrm{c}(\mathrm{RGDyK}))_{2}$, was labeled with ${ }^{18} \mathrm{~F}$ via a prosthetic $4-\left[{ }^{18} \mathrm{~F}\right]$ fluorobenzoyl moiety. ${ }^{46}$ In in vivo studies, the resulting $\left[{ }^{18} \mathrm{~F}\right] \mathrm{FB}-\mathrm{E}(\mathrm{c}(\mathrm{RGDyK}))_{2}$ showed significantly higher tumor uptake and prolonged tumor retention, compared with its monomeric analog, $\left[{ }^{18} \mathrm{~F}\right] \mathrm{FB}-\mathrm{c}(\mathrm{RGDyK})$. In addition, the dimeric peptide had a predominant renal excretion, whereas the monomeric analog was excreted preliminary through the biliary route.

The group in Munich developed the pentapeptide cyclo(RGDfE-) for multimerization of RGD peptides. ${ }^{47}$ In their studies, glutamic acid was chosen as the fifth amino acid, since it provides a free carboxylic group for peptide-coupling reactions. cyclo(-RGDfE-), and was linked to either aminohexanoic acid (Ahx) or to heptaethylene glycol (HEG) as spacer molecules. Subsequently, these monomeric units were

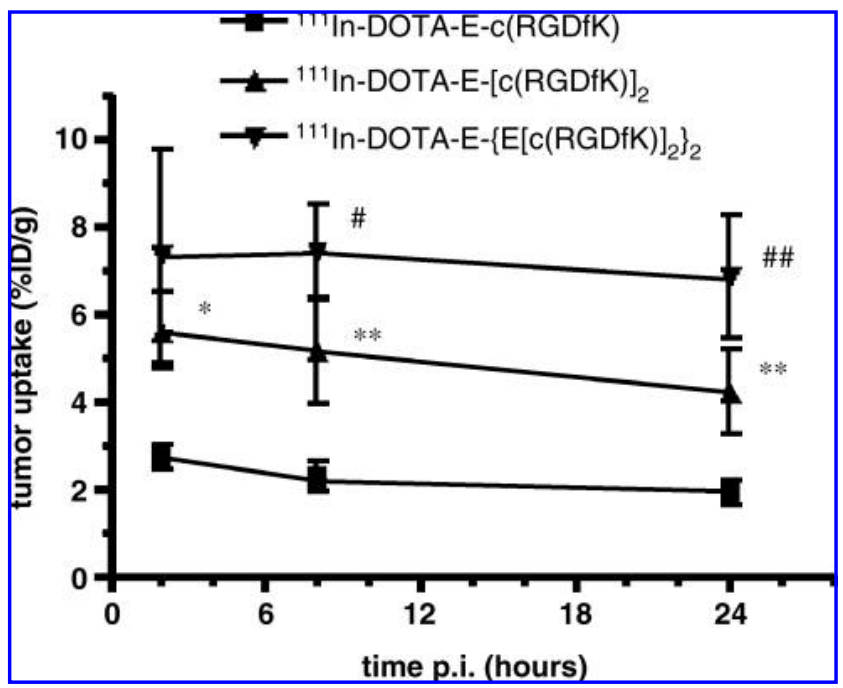

FIG. 2. Tumor uptake of ${ }^{111}$ In-DOTA-E-c(RGDfK), ${ }^{111} \mathrm{In}-$ DOTA-E-[c(RGDfK) $]_{2}$, and ${ }^{111}$ In-DOTA-E $\{$ E[c(RGDfK $\left.\left.)\right]_{2}\right\}_{2}$ at 2,8 , and 24 hours after injection in athymic mice with subcutaneous SK-RC-52 tumors. Results are reflected as mean injected dose per gram \pm standard deviation. Values were analyzed by using one-way analysis of variance. ${ }^{*} p<0.05$; ${ }^{* *} p<0.01$; ${ }^{\#} p<0.05 ;{ }^{\# \#} p<0.01$. $p$-values refer to differences in tumor uptake between ${ }^{111}$ In-DOTA-E-c(RGDfK) and ${ }^{111} \mathrm{In}$ DOTA-E- $[\mathrm{c}(\mathrm{RGDfK})]_{2}$ or differences in tumor uptake between ${ }^{111}$ In-DOTA-E-[C(RGDfK) $]_{2}$ and ${ }^{111}$ In-DOTA-E $\{\mathrm{E}[\mathrm{C}$ $\left.(\text { RGDfK) }]_{2}\right\}_{2}$. bridged via lysine or lysine tree to form dimeric and tetrameric RGD peptides. The final ${ }^{18}$ F-labeling step was carried out by oxime ligation, for example, by using 4 - $\left[{ }^{18} \mathrm{~F}\right]$ fluorobenzaldehyde as the ${ }^{18} \mathrm{~F}$-labeled synthon. In in vitro studies, the multimers showed significantly increased affinity to $\alpha_{\mathrm{v}} \beta_{3}$ : monomer $<$ dimer $<$ tetramer. For example, $\alpha_{v} \beta_{3}$-affinities of the cyclo(-RGDfE-)-mono-, di-, and tetramer containing HEG spacer units were increased by a factor of 10 with each duplication of binding units $\left(\mathrm{IC}_{50}=20,3.0\right.$, and $0.2 \mathrm{nM}$, respectively for the mono-, di-, and tetramer). In mice with $\alpha_{\mathrm{v}} \beta_{3}$-positive M21-melanoma, ${ }^{48}$ the tumor uptake of the ${ }^{18} \mathrm{~F}$ labeled RGD peptides increased in the series monomer $<$ dimer $\approx$ tetramer, but due to lower uptake of the tetramer in all other tissues, compared to the dimer, tumor-to-organ ratios were highest for the ${ }^{18} \mathrm{~F}$-labeled RGD-tetramer, leading to a significant improved imaging. ${ }^{48,49}$

Although the potential benefits of multivalent probes are generally accepted, the exact mechanism of the enhanced accumulation in $\alpha_{\mathrm{v}} \beta_{3}$-expressing tumors is not exactly clear. It is unlikely that these multimers bind several $\alpha_{\mathrm{v}} \beta_{3}$ integrins simultaneously, because the distance between the RGD units is very short. Statistical rebinding is the most likely explanation for the enhanced affinity of the multimers, compared to their monomeric counterparts. Due to the incorporation of Ahx- or HEG-spacers, the distance between the cyclo(RGDfE) moieties might be long enough to bind adjacent $\alpha_{\mathrm{v}} \beta_{3}$ integrins simultaneously and thus multivalently. Recently, Liu et al. extended the distance between two RGD motifs by $\mathrm{PEG}_{4}$ linkers, resulting in a higher affinity and a significantly higher tumor uptake, compared with the dimer without linkers. ${ }^{50}$

During recent years, various other RGD dimers, tetramers, and even octamers labeled with different radionuclides have been developed and studied in vitro and in vivo. ${ }^{51-59}$ Generally, the results from several research groups have demonstrated that increasing the peptide multiplicity can significantly enhance the integrin $\alpha_{\mathrm{v}} \beta_{3}$-binding affinity of RGD peptides and improve tumor-targeting capability of the radiotracer (Fig. 3). ${ }^{60}$ In addition, the incorporation of the right spacer between the RGD motifs can enhance the affinity

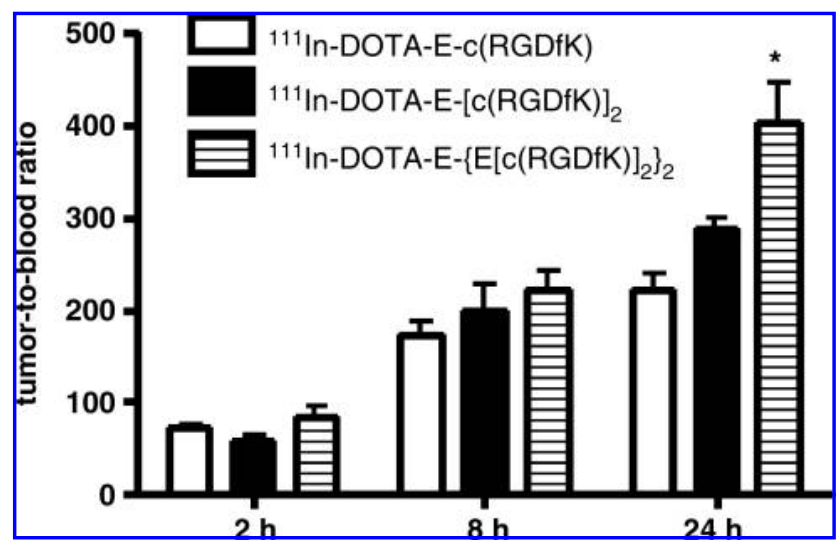

FIG. 3. Tumor-to-blood ratios of ${ }^{111}$ In-DOTA-E-c(RGDfK), ${ }^{111}$ In-DOTA-E-[c(RGDfK) $]_{2}$, and ${ }^{111}$ In-DOTA-E $\left\{\mathrm{E}[\mathrm{c}(\mathrm{RGDfK})]_{2}\right\}_{2}$ at 2, 8, and 24 hours after injection in athymic mice with subcutaneous SK-RC-52 tumors. Each bar represents the mean values \pm standard deviation. Values were analyzed by using one-way analysis of variance. ${ }^{*} p<0.05$. 
for $\alpha_{\mathrm{v}} \beta_{3}$ and improve the tumor uptake. Among mono-, di-, tetra-, and octameric cyclo(RGDfK)-based peptides, the octamer had the highest $\alpha_{v} \beta_{3}$ affinity and, usually, the highest tumor uptake. From this point of view, further increase of RGD peptide multiplicity may result in the formation of oligo- or polymeric cyclic RGD peptides with improved integrin $\alpha_{\mathrm{v}} \beta_{3}$-binding affinity and tumor targeting efficacy.

\section{Integrin $\alpha_{5} \beta_{1}$}

The $\alpha_{5} \beta_{1}$ integrin, also known as very late antigen-5 (VLA5 , fibronectin receptor), is the only integrin heterodimer that contains the $\alpha_{5}$-subunit. ${ }^{61-63}$ This integrin functions as a receptor for fibronectin and certain other ECM proteins. ${ }^{62}$ Integrin $\alpha_{5} \beta_{1}$ is poorly expressed on quiescent endothelium, but its expression is significantly upregulated on endothelium during tumor angiogenesis in both mice and humans. ${ }^{64}$ $\alpha_{5} \beta_{1}$-binding ligands are currently under development. Radiolabeled high-affinity $\alpha_{5} \beta_{1}$-binders might be more selective tracers to image angiogenic processes in animal models and patients than $\alpha_{\mathrm{v}} \beta_{3}$-binding tracers.

\section{VEGF Receptors}

VEGF is a key regulator of angiogenesis during embryogenesis, skeletal growth, and reproductive functions. The expression of VEGF is upregulated by environmental stress caused by hypoxia, anemia, myocardial ischemia, and tumor progression to initiate neovascularization. ${ }^{65}$ Via alternative mRNA splicing, the human VEGF-A gene gives rise to four isoforms having 121, 165, 189, and 206 amino acids $\left(\mathrm{VEGF}_{121}, \mathrm{VEGF}_{165}, \mathrm{VEGF}_{189}\right.$, and $\mathrm{VEGF}_{206}$, respectively). ${ }^{66,67}$ Less-frequent splice variants have been identified more recently, including $\mathrm{VEGF}_{145},{ }^{68} \mathrm{VEGF}_{183},{ }^{69} \mathrm{VEGF}_{162}{ }^{70}$ and VEGF $_{165 \mathrm{~b}}{ }^{71}$ The VEGF isoforms differ not only in their molecular mass, but also in their solubility and receptorbinding characteristics.

Initially, VEGF receptors were identified on the cell surface of vascular endothelial cells in vitro ${ }^{72,73}$ and in vivo. ${ }^{74,75}$ Subsequently, it was demonstrated that receptors for VEGF also occur on bone-marrow-derived cells, such as monocytes. $^{76}$ VEGF binds two related receptor tyrosine kinases (RTKs), VEGFR-1 and VEGFR-2. Both receptors consist of seven Ig-like domains in the extracellular domain, a single transmembrane region, and a consensus tyrosine kinase sequence that is interrupted by a kinase-insert domain. ${ }^{77-79}$
VEGFR-1 binds VEGF with a higher affinity, compared to VEGFR-2 ( $K_{\mathrm{d}}$ : 25 versus $\left.75-250 \mathrm{pM}\right) .{ }^{80-82}$ VEGFR-1 is considered to be a decoy receptor and VEGF-A only signals through VEGFR-2. ${ }^{83}$

Bevacizumab is a humanized variant of the anti-VEGF-A monoclonal antibody $(\mathrm{mAb})$, A.4.6.1. It is directed against a common epitope encoded by exon 4, present on all VEGFisoforms, and prevents interaction with VEGFR-1 and VEGFR-2. ${ }^{84}$ Nagengast et al. were the first to demonstrate noninvasive VEGF imaging from using radiolabeled bevacizumab. In their study, they demonstrated the potential of ${ }^{89} \mathrm{Zr}$ - and ${ }^{111} \mathrm{In}$-bevacizumab as a specific VEGF tracer in nude mice with human SKOV-3 ovarian tumor xenografts. ${ }^{85}$ At the same time, our group showed specific imaging of VEGF-A expression from using ${ }^{111}$ In-bevacizumab in mice with s.c. human colon carcinoma xenografts LS174T (Fig. 4). ${ }^{86}$ We were the first to investigate the potential of ${ }^{111}$ In-labeled bevacizumab to image the expression of VEGF-A in tumors in cancer patients. In a study in colorectal cancer patients with liver metastases, the liver metastases in 9 of 12 patients were visualized with ${ }^{111}$ In-bevacizumab. In this study, the liver metastases were resected after scintigraphic imaging, allowing further immunohistochemical analysis. The VEGFA expression in these resected liver metastases was determined by in situ hybridization and by enzyme-linked immunosorbent assay (ELISA). Surprisingly, no correlation was found between the level of antibody accumulation and expression of VEGF-A.

Cai et al. labeled $\mathrm{VEGF}_{121}$ with ${ }^{64} \mathrm{Cu}$ via DOTA for PET imaging of VEGFR expression. ${ }^{87}$ Small-animal PET imaging revealed rapid, specific, and prominent uptake of ${ }^{64} \mathrm{Cu}$-DOTAVEGF $_{121}$ in highly vascularized small U87MG human glioblastoma tumors (high VEGFR expression), but significantly lower uptake in large U87MG tumors (low VEGFR expression).

\section{Matrix Metalloproteinases}

Matrix metalloproteinases (MMPs) are a family of more than 20 extracellular proteins, which are able to degrade structural components of the extracellular matrix (ECM) and basement membranes with overlapping substrate specificity. ${ }^{88-90} \mathrm{MMPs}$ are zinc- and calcium-dependent secreted or membraneanchored endopeptidases. They play a role in several physiologic processes, including angiogenesis, embryonic development, tissue morphogenesis, and wound healing. However,

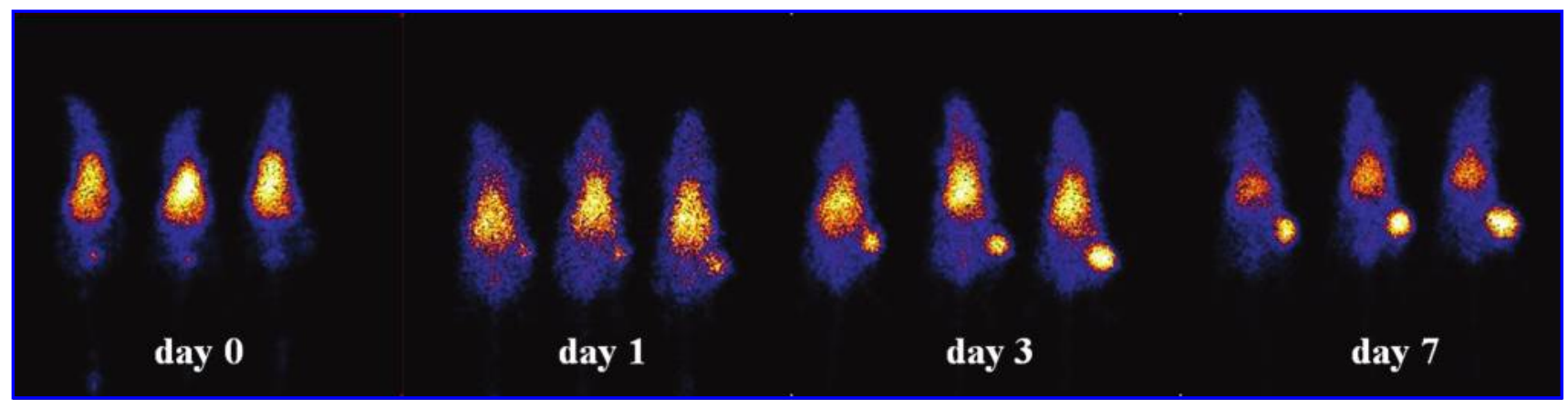

FIG. 4. Scintigraphic images of 3 athymic male mice with subcutaneous LS174T tumors immediately after injection and at 1 , 3 , and 7 days postinjection of ${ }^{111}$ In-bevacizumab $(0.9 \mathrm{MBq} / \mathrm{mouse}, 3 \mu \mathrm{g} / \mathrm{mouse})$. 
MMP expression and activity are upregulated under many pathologic conditions, such as atherosclerosis, inflammatory processes, and angiogenesis in tumors. ${ }^{91,92}$ In epithelial tumors, most of the upregulated MMPs are expressed by the host stromal cells. ${ }^{93}$ Expression of MMPs is associated with the removal of the ECM barrier to allow cancer cells and endothelial cells to invade the tissue. A number of MMPs are specifically involved in angiogenesis, including MMPs 1, 2, 3, 9, and 14 . There is a growing interest in the use of radiolabeled MMP ligands as tracers to image angiogenesis in tumors and their potential to metastasize possibly. ${ }^{94-96}$

Using phage display libraries, Koivunen et al. found that cyclo(Cys-Thr-Thr-His-Trp-Gly-Phe-Thr-Leu-Cys) (CTT), a disulfide-bridged decapeptide, selectively inhibited MMP2 and $9 .{ }^{97}$ CTT reduced the migration of both human endothelial and tumor cells and prevented tumor growth and invasion in animal models. The Munich group derivatized, radioiodinated, and evaluated CTT as a tracer for imaging MMP2 and 9 activity. In in vivo studies, CTT demonstrated high lipophilicity, resulting in high liver and kidney uptake. In addition, this peptide showed low tumor uptake due to the poor stability of the ${ }^{125} \mathrm{I}-\mathrm{D}$-Tyr-modified peptide. In another study, CTT was conjugated to the chelator, DOTA, for radiolabeling with ${ }^{64} \mathrm{Cu}$ and subsequent microPET imaging of MMP2/9-expressing tumors. ${ }^{98}$ Although there was some evidence for selective uptake of ${ }^{64} \mathrm{Cu}$-DOTA-CTT by MMP2and MMP9-expressing tumors, this tracer had a low affinity for MMP2 and MMP-9 and showed low accumulation in tumors.

The above-mentioned radiotracers are based on the application of peptides for the imaging of activated MMPs. Another approach is based on the use of small-molecule nonpeptidyl matrix metalloproteinase inhibitors (MMPIs). These nonpeptidyl tracers for MMP imaging were reviewed recently. ${ }^{99}$ The $N$-sulfonyl amino acid hydroxamates, CGS 25966 and CGS 27023A, appeared to be prominent lead structures for potential radiolabeled tracers. These lead compounds inhibit MMP1, 2, 3, and 9 by chelating the zinc ion of the enzyme active site with the hydroxamic acid moiety. ${ }^{100,101}$ Lately, the ${ }^{123}$ I-labeled CGS 27023A-derivative $\left[{ }^{123} \mathrm{I}\right] \mathrm{I}-\mathrm{HO}-\mathrm{CGS} 27023 \mathrm{~A}$ has been synthesized and was tested in vitro and in vivo. This radiotracer specifically visualized activated MMPs in vascular lesions developing after carotid artery ligation in apolipoprotein E-deficient $\left(\mathrm{ApoE}^{-/-}\right)$mice by means of planar scintigraphy. ${ }^{102,103}$ Then, research groups focused on the development of several PET-compatible, mainly ${ }^{11} \mathrm{C}$ - and ${ }^{18} \mathrm{~F}$-labeled, CGS 25966 and CGS 27023A derivatives. ${ }^{104-107}$ Preclinical evaluation of these tracers was either not successful ${ }^{108}$ or not published. ${ }^{104,105}$

Recently, novel fluorinated MMPIs, based on the lead structures, CGS 25966 and CGS 27023A, were synthesized and the inhibition potencies of the compounds were evaluated in in vitro MMP inhibition assays for MMP2, 8, 9, and 13. With the exception of one compound, all fluorinated hydroxamates are still potent, broad-spectrum MMPIs $\left(\mathrm{IC}_{50}=0.5-527 \mathrm{nM}\right)$. Subsequent biodistribution and metabolism studies of two radioligands $\left(\left[{ }^{18} \mathrm{~F}\right] 1 \mathrm{f}\right.$ and $\left.\left[{ }^{18} \mathrm{~F}\right] 1 \mathrm{j}\right)$ in wild-type (WT) mice demonstrated no tissue-specific accumulation, which may be an advantage in the study of activated and dysregulated MMPs. This new class of hydroxamate-based radioligands could evolve into tracers for noninvasive detection of activated MMPs.

\section{Prostate-Specific Membrane Antigen}

Prostate-specific membrane antigen (PSMA) is a transmembrane protein that is overexpressed in prostate cancer. The anti-PSMA antibody, capromab pendetide, labeled with ${ }^{111} \mathrm{In}$, is marketed as ProstaScint, a U.S. Food and Drug Administered (FDA)-approved antibody preparation for the detection of nodal metastases in prostate cancer patients. ${ }^{109}$ However, this antibody is directed against an intracellular epitope of PSMA, which is considered a suboptimal target for antibody imaging. PSMA was also found to be expressed on the neovascular endothelium of most solid tumor types, while there is no expression on the endothelial cells of normal tissue. ${ }^{110}$

J591 is a mAb directed against an epitope on the extracellular domain of PSMA. ${ }^{111}$ Previous studies have shown that J591 accumulated in metastatic prostate cancer lesions. ${ }^{112}$ In a recent phase I trial, the feasibility of targeting the neovasculature of a wide range of adenocarcinomas, using ${ }^{111}$ In-labeled humanized J591, was investigated. Patients with melanoma and cancers of the breast, colon, liver, and kidney were injected with ${ }^{111}$ In-J591. In these patients $(n=24)$ the antibody accreted in all known tumor sites. Seventeen (17) of $18(94 \%)$ patients with soft tissue disease on standard scans showed uptake in the soft tissues on antibody scans, as did 6 of 6 patients with bone disease. These data show selective targeting of PSMA expressed on tumor endothelium. ${ }^{113}{ }^{111}$ In-huJ591 has the potential to become a suitable tracer for imaging angiogenesis.

More recently, the first PET imaging agent for PSMA was synthesized in an extension of their previous work with the ${ }^{11} \mathrm{C}$-labeled DCMC, which binds to the active carboxy peptidase site of PSMA. ${ }^{114}$ Mease et al. synthesized an agent containing ${ }^{18} \mathrm{~F}$ : ${ }^{18} \mathrm{~F}$-DCFBC. ${ }^{18} \mathrm{~F}$-DCFBC was demonstrated to localize in PSMA-expressing tumors in mice, allowing imaging by small animal PET. ${ }^{115}$

\section{ECM Proteins}

A few antigens in the ECM have been identified that are preferentially expressed in the surroundings of newly formed blood vessels.

\section{Extra domain $B$ of fibronectin}

Fibronectin is a large glycoprotein in the ECM. The extra domain B (ED-B) of fibronectin is a sequence of 91 amino acids, identical in mice, rats, and humans, that can be inserted into the fibronectin molecule at sites of tissue remodeling by alternative splicing. ED-B is specifically expressed around neovascular structures in tumors and other tissues undergoing angiogenesis, but is undetectable in the normal adult tissues. ${ }^{116}$ Using phage display technology, single-chain antibodies $(\mathrm{scFv})$ directed against EDB have been isolated. ${ }^{117,118}$ The human single-domain antibody ( $\mathrm{scFv}), \mathrm{L} 19$, was shown to have subnanomolar affinity for ED-B. ${ }^{119}$

Demartis et al. showed that radioiodinated scFv L19 selectively accumulated around tumoral blood vessels in a murine tumor model. Since the ED-B domain of fibronectin has an identical sequence in mouse and man, they suggested clinical utility for the scintigraphic detection of angiogenesis in vivo. ${ }^{120}$ Two (2) years later, it was shown by scintigraphic imaging that ${ }^{123}$ I-L19 selectively localized in tumor lesions of 
aggressive lung cancer as well as in liver metastases of colorectal cancer patients. ${ }^{121}$ More recently, the amino-acid sequence, (Gly)3-Cys-Ala, was inserted at the C-terminus of L19, resulting in the anti-ED-B scFv, named AP39, which could be labeled with ${ }^{99 \mathrm{~m}} \mathrm{Tc}$. The data revealed the feasibility of targeting ED-B fibronectin with ${ }^{99 \mathrm{~m}} \mathrm{Tc}$-labeled L19 in nude mice with s.c. teratocarcinoma tumors. ${ }^{122}$

Subsequently, a series of different L19 formats were constructed, including dimeric $\mathrm{scF}$, a human bivalent "small immunoprotein" (SIP), and a complete human IgG. In comparing these different formats labeled with ${ }^{125} \mathrm{I} /{ }^{131} \mathrm{I}, \mathrm{L} 19-\mathrm{SIP}$ proved to be the most suitable tracer for imaging ED-B expression in tumors. In 2007, Rossin et al. described ${ }^{76} \mathrm{Br}-\mathrm{L} 19-$ SIP, the first PET-imaging derivative of L19, for imaging of neovasculature in xenograft-bearing nude mice. Besides clear tumor targeting, ${ }^{76} \mathrm{Br}$-L19-SIP also showed persistent activity in blood, stomach, and several other normal organs, most probably due to in vivo debromination. ${ }^{123}$

\section{Extra domain $C$ of tenascin}

Tenascin is an ECM component. Tenascin- $C$, containing the extra domain $C$, is a splice variant of tenascin. Overexpression of this splice variant has been reported in highgrade astrocytomas, with a prominent pattern of staining around tumor neovasculature. In contrast, domain $\mathrm{C}$ was undetectable in normal human tissues and by immunohistochemistry and even at the level of Northern blot analysis. $^{124}$

Recently, Silacci et al. reported that the extra domain $C$ is strongly expressed in the majority of lung cancers, with a vascular and stromal pattern of expression. Using antibody phage technology, they have generated a high-affinity human antibody fragment (G11), which was shown to selectively target tenascin-C in s.c. U87 gliomas in mice. ${ }^{125}$ These results pave the way for the clinical development of the G11 antibody for imaging angiogenesis.

\section{Magic Roundabout (Robo-4)}

Magic roundabout (Robo-4) is the fourth recently identified member of the roundabout receptor family. ${ }^{126}$ Robo-1-3 are highly expressed in the nervous system and are involved in axon guidance. ${ }^{127}$ The specificity of Robo-4 expression, however, is unique, compared with the other three members; it is highly expressed in embryonic vasculature, but not in the nervous system. ${ }^{128}$ Robo- 4 induces endothelial migration and regulates angiogenesis. Some reports suggest that Robo-4 is expressed exclusively in tumor neovascular endothelium, and currently, Robo- 4 is considered a highly specific marker of tumor endothelium. ${ }^{129}$ The ligand of Robo- 4 has not been identified yet. It does not bind to slit2, the common ligand of Robo-1-3. ${ }^{130}$ Further studies are needed to identify the ligands of Robo- 4 . Based on these ligand(s), a tracer could be developed that can image the expression of Robo- 4 in tumors.

\section{Conclusions}

Clinical trials of antiangiogenic drugs are challenging because there is no established method to monitor the effect of these drugs. It has been suggested that the maximum tolerated dose of antiangiogenic drugs is not necessarily the most effective. ${ }^{131}$ Establishing the optimal dose of an anti- angiogenic agent, based on tumor-size measurements or on time to disease progression, may take months or years. ${ }^{132}$ Further, in patients, tumors typically develop resistance to antiangiogenic drugs after 6-12 months of treatment. ${ }^{133}$ Surrogate markers of angiogenesis are considered to be useful not only for the stratification of patients for treatment with antiangiogenic drugs, but also to determine optimal dosing, early clinical benefit, and the development of resistance. Biomarkers could also become essential to justify the costs of targeted therapies by increasing the likelihood of benefit to a level that is acceptable to patients and clinicians.

Numerous markers of tumor vasculature have been identified, but only a few radiotracers of angiogenesis have been tested clinically. The most extensively studied marker of angiogenesis is the integrin, $\alpha_{\mathrm{v}} \beta_{3}$. For this marker, the single-photon emission computed tomography-tracer, ${ }^{99 \mathrm{~m}} \mathrm{Tc}$ NC100692, and the PET tracer, ${ }^{18}$ F-galacto-RGD, have been successfully tested in humans.

Other targets exclusively expressed on activated endothelial cells may eventually be better targets for imaging angiogenesis. Of the identified markers, PSMA, Robo-4, and $\alpha_{5} \beta_{1}$ seem to be specifically expressed on tumor neovasculature.

In conclusion, a few radiotracers for imaging angiogenesis in tumors have been tested in humans. The role of these tracers in assessing the response to antiangiogenic therapies has yet to be assessed.

\section{Acknowledgments}

The authors would like to thank Ambros J. Beer, Ph.D., at the Technische Universität München for providing the PET and the PET/CT-, PET/MRI-fusion images.

\section{Disclosure Statement}

No competing financial interests exist.

\section{References}

1. Ferrara N. Vascular endothelial growth factor and the regulation of angiogenesis. Recent Prog Horm Res 2000;55: 15.

2. Kuwano M, Fukushi J, Okamoto $M$, et al. Angiogenesis factors. Intern Med 2001;40:565.

3. Ellis LM, Liu W, Ahmad SA, et al. Overview of angiogenesis: Biologic implications for antiangiogenic therapy. Semin Oncol 2001;28:94.

4. Yancopoulos GD, Davis S, Gale NW, et al. Vascular-specific growth factors and blood vessel formation. Nature 2000; 407:242.

5. Carmeliet P. Mechanisms of angiogenesis and arteriogenesis. Nat Med 2000;6:389.

6. Harris AL. Hypoxia-a key regulatory factor in tumour growth. Nat Rev Cancer 2002;238.

7. Eliceiri BP, Cheresh DA. The role of alphav integrins during angiogenesis. Mol Med 1998;4:741.

8. Hynes RO, Bader BL, Hodivala-DilkeK. Integrins in vascular development. Braz J Med Biol Res 1999;32:501.

9. Pepper MS. Role of the matrix metalloproteinase and plasminogen activator-plasmin systems in angiogenesis. Arterioscler Thromb Vasc Biol 2001;21:1104.

10. Leenders WP, Kusters B, de Waal RM. Vessel co-option: How tumors obtain blood supply in the absence of sprouting angiogenesis. Endothelium 2002;9:83. 
11. Tamkun J, DeSimone D, Fonda D, et al. Structure of integrin, a glycoprotein involved in the transmembrane linkage between fibronectin and actin. Cell 1986;46:271.

12. Aplin AE, Howe A, Alahari SK, et al. Signal transduction and signal modulation by cell adhesion receptors: The role of integrins, cadherins, immunoglobulin-cell adhesion molecules, and selectins. Pharmacol Rev 1998;50:197.

13. Schoenwaelder S, Burridge K. Bidirectional signaling between the cytoskeleton and integrins. Curr Opin Cell Biol 1999;11:274.

14. Frisch S, Ruoslahti E. Integrins and anoikis. Curr Opin Cell Biol 1997;9:701.

15. Howe A, Aplin A, Alahari S, et al. Integrin signaling and cell growth control. Curr Opin Cell Biol 1998;10:220.

16. Brooks P, Clark R, Cheresh D. Requirement of vascular integrin alphavbeta3 for angiogenesis. Science 1994;264: 569.

17. Cheresh D. Integrins: Structure, function, and biological properties. Adv Mol Cell Biol 1993;6:225.

18. Aumailley M, Gurrath M, Müller G, et al. Arg-Gly-Asp constrained within cyclic pentapeptides. Strong and selective inhibitors of cell adhesion to vitronectin and laminin fragment P1. FEBS Lett 1991;291:50.

19. Gurrath M, Müller G, Kessler H, et al. Conformation/ activity studies of rationally designed potent anti-adhesive RGD peptides. Eur J Biochem 1992;210:911.

20. Haubner R, Gratias R, Diefenbach B, et al. Structural and functional aspects of RGD-containing cyclic pentapeptides as highly potent and selective integrin alphavbeta3 antagonists. I Am Chem Soc 1996;118:7461.

21. Haubner R, Wester H-J, Reuning U, et al. Radiolabeled alphavbeta3 integrin antagonists: A new class of tracers for tumor targeting. J Nucl Med 1999;40:1061.

22. Haubner R, Wester H-J, Burkhart F, et al. Glycosylated RGD-containing peptides: Tracer for tumor targeting and angiogenesis imaging with improved biokinetics. I Nucl Med 2001;42:326.

23. Haubner R, Kuhnast B, Mang C, et al. $\left[{ }^{18} \mathrm{~F}\right]$ Galacto-RGD: Synthesis, radiolabeling, metabolic stability, and radiation dose estimates. Bioconj Chem 2004;15:61.

24. Van Hagen PM, Breeman WA, Bernard HF, et al. Evaluation of a radiolabelled cyclic DTPA-RGD analogue for tumour imaging and radionuclide therapy. Int J Cancer 2000;90:186.

25. Chen X, Park R, Shahinian A, et al. Pharmacokinetics and tumor retention of ${ }^{125}$ I-labeled RGD peptide are improved by PEGylation. Nucl Med Biol 2004;31:11.

26. Chen X, Hou Y, Tohme M, et al. Pegylated Arg-GlyAsp peptide: ${ }^{64} \mathrm{Cu}$ labeling and PET imaging of brain tumor alphavbeta3-integrin expression. J Nucl Med 2004; 45:1776.

27. Chen X, Park R, Hou Y, et al. MicroPET imaging of brain tumor angiogenesis with ${ }^{18} \mathrm{~F}$-labeled PEGylated RGD peptide. Eur J Nucl Med Mol Imaging 2004;31:1081.

28. Lindsey ML, Escobar GP, Dobrucki LW, et al. Matrix metalloproteinase-9 gene deletion facilitates angiogenesis after myocardial infarction. Am J Physiol Heart Circ Physiol 2006;290:H232.

29. Hua J, Dobrucki L, Sadeghi M, et al. Noninvasive imaging of angiogenesis with a ${ }^{99 \mathrm{~m}} \mathrm{Tc}$-labeled peptide targeted at alphavbeta3 integrin after murine hindlimb ischemia. Circulation 2005;111:3255.

30. Haubner R, Weber W, Beer A, et al. Noninvasive visualization of the activated alphavbeta3 integrin in cancer patients by positron emission tomography and $\left[{ }^{18} \mathrm{~F}\right] \mathrm{Ga}-$ lacto-RGD. PLoS Med 2005;2:e70.

31. Beer A, Haubner R, Goebel M, et al. Biodistribution and pharmacokinetics of the alphavbeta3 selective tracer ${ }^{18} \mathrm{~F}$ Galacto-RGD in cancer patients. I Nucl Med 2005;46: 1333.

32. Beer A, Haubner R, Wolf I, et al. Martinez MJ, Wester HJ, Weber W, Schwaiger M. PET-based human dosimetry of ${ }^{18}$ F-galacto-RGD, a new radiotracer for imaging alphav beta3 expression. J Nucl Med 2006;47:763.

33. Stangier I, Wester HJ, Schwaiger M, et al. Comparison of standardised uptake values and distribution volume for imaging of alphavbeta3 expression in breast cancer patients with $\left[{ }^{18}\right.$ F]Galacto-RGD PET[abstract]. J Nucl Med 2007;48:(S2)406.

34. Beer A, Haubner R, Sarbia M, et al. Positron emission tomography using $\left[{ }^{18} \mathrm{~F}\right]$ Galacto-RGD identifies the level of integrin alphavbeta 3 expresssion in man. Clin Cancer Res 2006;12:3942.

35. Beer A, Lorenzen S, Metz S, et al. Comparison of integrin alphavbeta3 expression and glucose metabolism in primary and metastatic lesions in cancer patients: A PET study us-

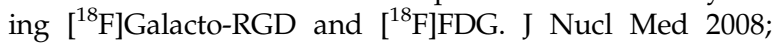
49:22.

36. Bach-Gansmo T, Danielsson R, Saracco A, et al. Integrin receptor imaging of breast cancer: A proof-of-concept study to evaluate ${ }^{99 \mathrm{~m}}$ Tc-NC100692. J Nucl Med 2006;47:1434.

37. Bach-Gansmo T, Bogsrud TV, Skretting A. Integrin scintimammography using a dedicated breast imaging, solidstate gamma-camera, and (99m)Tc-labelled NC100692. Clin Physiol Funct Imaging 2008;28:235.

38. Rajopadhye M, Harris AR, Nguyen HM, et al. RP593, a ${ }^{99 \mathrm{~m}}$ Tc-labeled $\alpha_{\mathrm{v}} \beta_{3} / \alpha_{\mathrm{v}} \beta_{5}$ antagonist, rapidly detects spontaneous tumors in mice and dogs. J Nucl Med 2000;41:34P.

39. Liu S, Edwards DS, Ziegler MC, et al. ${ }^{99 \mathrm{~m}} \mathrm{Tc}$-labeling of a hydrazinonicotinamide-conjugated vitronectin receptor antagonist useful for imaging tumors. Bioconjug Chem 2001;12:624

40. Liu S, Cheung E, Ziegler MC, et al. (90)Y and (177)Lu labeling of a DOTA-conjugated vitronectin receptor antagonist useful for tumor therapy. Bioconjug Chem 2001;12: 559.

41. Janssen ML, Oyen WJ, Dijkgraaf I, et al. Tumor targeting with radiolabeled alpha(v)beta(3) integrin binding peptides in a nude mouse model. Cancer Res 2002;62:6146.

42. Janssen M, Oyen WJ, Massuger LF, et al. Comparison of a monomeric and dimeric radiolabeled RGD-peptide for tumor targeting. Cancer Biother Radiopharm 2002;17:641.

43. Janssen M, Frielink C, Dijkgraaf I, et al. Improved tumor targeting of radiolabeled RGD peptides using rapid dose fractionation. Cancer Biother Radiopharm 2004;19:399.

44. Liu S, Hsieh WY, Kim YS, et al. Effect of coligands on biodistribution characteristics of ternary ligand ${ }^{99} \mathrm{~m} \mathrm{Tc}$ complexes of a HYNIC-conjugated cyclic RGDfK dimer. Bioconjug Chem 2005; 16:1580.

45. Chen X, Liu S, Hou Y, et al. MicroPET imaging of breast cancer alphav-integrin expression with ${ }^{64} \mathrm{Cu}$-labeled dimeric RGD peptides. Mol Imaging Biol 2004;6:350.

46. Chen X, Tohme M, Park R, et al. Micro-PET imaging of alphavbeta3-integrin expression with ${ }^{18}$ F-labeled dimeric RGD peptide. Mol Imaging 2004;3:96.

47. Thumshirn G, Hersel U, Goodman S, et al. Multimeric cyclic RGD peptides as potential tools for tumor targeting: Solid-phase peptide synthesis and chemoselective oxime ligation. Chemistry 2003;9:2717. 
48. Poethko T, Schottelius M, Thumshirn G, et al. Chemoselective preconjugate radiohalogenation of unprotected mono- and multimeric peptides via oxime formation. Radiochim Acta 2004;92:317.

49. Poethko T, Schottelius M, Thumshirn G, et al. Two-step methodology for high-yield routine radiohalogenation of peptides: (18)F-labeled RGD and octreotide analogs. J Nucl Med 2004;45:892.

50. Liu Z, Liu S, Wang F, et al. Noninvasive imaging of tumor integrin expression using (18)F-labeled RGD dimer peptide with PEG(4) linkers. Eur J Nucl Med Mol Imaging Epub 2009 Mar 19.

51. Li ZB, Cai W, Cao Q, et al. (64)Cu-labeled tetrameric and octameric RGD peptides for small-animal PET of tumor alpha (v)beta (3) integrin expression. I Nucl Med 2007; 48:1162.

52. Liu S, Hsieh WY, Jiang Y, et al. Evaluation of a (99m)Tclabeled cyclic RGD tetramer for noninvasive imaging integrin alpha (v)beta3-positive breast cancer. Bioconj Chem 2007;18:438.

53. Cheng Z, Wu Y, Xiong Z, et al. Near-infrared fluorescent RGD peptides for optical imaging of integrin alphavbeta3 expression in living mice. Bioconj Chem 2005;16:1433.

54. Wu Y, Zhang X, Xiong Z, et al. microPET imaging of glioma integrin \{alpha\} $\{$ beta\}3 expression using (64)Cu-labeled tetrameric RGD peptide. I Nucl Med 2005;46: 1707.

55. Dijkgraaf I, Rijnders AY, Soede A, et al. Synthesis of DOTA-conjugated multivalent cyclic-RGD peptide dendrimers via 1,3-dipolar cycloaddition and their biological evaluation: Implications for tumor targeting and tumor imaging purposes. Org Biomol Chem 2007;5:935.

56. Dijkgraaf I, Kruijtzer JA, Liu S, et al. Improved targeting of the alpha (v)beta (3) integrin by multimerisation of RGD peptides. Eur J Nucl Med Mol Imaging 2007;34:267.

57. Janssen M, Oyen WJ, Massuger LF, et al. Comparison of a monomeric and dimeric radiolabeled RGD-peptide for tumor targeting. Cancer Biother Radiopharm 2002;17:641.

58. Sancey L, Ardisson V, Riou LM, et al. In vivo imaging of tumour angiogenesis in mice with the alpha(v)beta (3) integrin-targeted tracer ${ }^{99 \mathrm{~m}}$ Tc-RAFT-RGD. Eur J Nucl Med Mol Imaging 2007;34:2037.

59. Ahmadi M, Sancey L, Briat A, et al. Chemical and biological evaluations of an ${ }^{111}$ In-labeled RGD-peptide targeting integrin alpha(V) beta(3) in a preclinical tumor model. Cancer Biother Radiopharm 2008;23:691.

60. Liu S. Radiolabeled multimeric cyclic RGD peptides as integrin alphavbeta3 targeted radiotracers for tumor imaging. Mol Pharm 2006;3:472.

61. Hynes RO. Integrins: Bidirectional, allosteric signaling machines. Cell 2002;110:673. Review.

62. Humphries JD, Byron A, Humphries MJ. Integrin ligands at a glance. J Cell Sci 2006;119:3901.

63. Kumar CC. Signaling by integrin receptors [review]. Oncogene 1998;17:1365.

64. Kim S, Bell K, Mousa SA, et al. Regulation of angiogenesis in vivo by ligation of integrin alpha5beta1 with the central cell-binding domain of fibronectin. Am J Pathol 2000;156: 1345.

65. Ferrara N. The role of VEGF in the regulation of physiological and pathological angiogenesis [review]. EXS 2005; 94:209.

66. Houck KA, Ferrara N, Winer J, et al. The vascular endothelial growth factor family: Identification of a fourth mo- lecular species and characterization of alternative splicing of RNA. Mol Endocrinol 1991;5:1806.

67. Tischer E, Mitchell R, Hartman T, et al. The human gene for vascular endothelial growth factor. Multiple protein forms are encoded through alternative exon splicing. J Biol Chem 1999;266:11947.

68. Poltorak Z, Cohen T, Sivan R, et al. VEGF145, a secreted vascular endothelial growth factor isoform that binds to extracellular matrix. J Biol Chem 1997;272:7151.

69. Jingjing L, Xue Y, Agarwal N, et al. Human Müller cells express VEGF183, a novel spliced variant of vascular endothelial growth factor. Invest Ophthalmol Vis Sci 1999;40: 752.

70. Lange T, Guttmann-Raviv N, Baruch L, et al. VEGF162, a new heparin-binding vascular endothelial growth factor splice form that is expressed in transformed human cells. J Biol Chem 2003;278:17164.

71. Bates DO, Cui TG, Doughty JM, et al. VEGF165b, an inhibitory splice variant of vascular endothelial growth factor, is down-regulated in renal cell carcinoma. Cancer Res 2002;62:4123.

72. Plouët J, Moukadiri H. Characterization of the receptor to vasculotropin on bovine adrenal cortex-derived capillary endothelial cells. I Biol Chem 1990;265:22071.

73. Vaisman N, Gospodarowicz D, Neufeld G. Characterization of the receptors for vascular endothelial growth factor. J Biol Chem 1990;265:19461.

74. Jakeman LB, Winer J, Bennett GL, et al. Binding sites for vascular endothelial growth factor are localized on endothelial cells in adult rat tissues. I Clin Invest 1992; 89:244.

75. Jakeman LB, Armanini M, Phillips HS, et al. Developmental expression of binding sites and messenger ribonucleic acid for vascular endothelial growth factor suggests a role for this protein in vasculogenesis and angiogenesis. Endocrinology 1993;133:848.

76. Ferrara N, Davis-Smyth T. The biology of vascular endothelial growth factor [review]. Endocr Rev 1997;18:4.

77. Shibuya M, Yamaguchi S, Yamane A, et al. Nucleotide sequence and expression of a novel human receptor-type tyrosine kinase gene (Flt) closely related to the fms family. Oncogene 1990;5:519.

78. Matthews W, Jordan CT, Gavin M, et al. A receptor tyrosine kinase cDNA isolated from a population of enriched primitive hematopoietic cells and exhibiting close genetic linkage to c-kit. Proc Natl Acad Sci U S A 1991;88:9026.

79. Terman BI, Carrion ME, Kovacs E, et al. Identification of a new endothelial cell growth factor receptor tyrosine kinase. Oncogene 1991;6:1677.

80. Terman BI, Dougher-Vermazen M, Carrion ME, et al. Identification of the KDR tyrosine kinase as a receptor for vascular endothelial cell growth factor. Biochem Biophys Res Commun 1992;187:1579.

81. Quinn TP, Peters KG, De Vries C, et al. Fetal liver kinase 1 is a receptor for vascular endothelial growth factor and is selectively expressed in vascular endothelium. Proc Natl Acad Sci U S A, 1993;90:7533.

82. Millauer B, Wizigmann-Voos S, Schnürch H, et al. Highaffinity VEGF binding and developmental expression suggest Flk-1 as a major regulator of vasculogenesis and angiogenesis. Cell 1993;72:835.

83. Shibuya M, Claesson-Welsh L. Signal transduction by VEGF receptors in regulation of angiogenesis and lymphangiogenesis. Exp Cell Res 2006;312:549. 
84. Presta LG, Chen H, O'Connor SJ, et al. Humanization of an anti-vascular endothelial growth factor monoclonal antibody for the therapy of solid tumors and other disorders. Cancer Res 1997;57:4593.

85. Nagengast WB, de Vries EG, Hospers GA, et al. In vivo VEGF imaging with radiolabeled bevacizumab in a human ovarian tumor xenograft. J Nucl Med 2007;48:1313.

86. Stollman TH, Scheer MG, Leenders WP, et al. Specific imaging of VEGF-A expression with radiolabeled anti-VEGF monoclonal antibody. Int J Cancer 2008;122:2310.

87. Cai W, Chen K, Mohamedali KA, et al. PET of vascular endothelial growth factor receptor expression. I Nucl Med 2006;47:2048.

88. Skiles JW, Gonnella NC, Jeng AY. The design, structure, and clinical update of small-molecular-weight matrix metalloproteinase inhibitors [review]. Curr Med Chem 2004; 11:2911.

89. Tayebjee MH, Lip GY, MacFadyen RJ. Matrix metalloproteinases in coronary artery disease: clinical and therapeutic implications and pathological significance [review]. Curr Med Chem 2005;12:917.

90. Beaudeux JL, Giral P, Bruckert E, et al. Matrix metalloproteinases, inflammation, and atherosclerosis: Therapeutic perspectives. Clin Chem Lab Med 2004;42:121.

91. Galis ZS, Khatri JJ. Matrix metalloproteinases in vascular remodeling and atherogenesis: The good, the bad, and the ugly [review]. Circ Res 2002;90:251.

92. George SJ. Therapeutic potential of matrix metalloproteinase inhibitors in atherosclerosis [review]. Exp Opin Investig Drugs 2000;9:993.

93. McKerrow JH, Bhargava V, Hansell E, et al. A functional proteomics screen of proteases in colorectal carcinoma. Mol Med 2000;6:450.

94. Bremer $\mathrm{C}$, Tung $\mathrm{CH}$, Weissleder R. In vivo molecular target assessment of matrix metalloproteinase inhibition. Nat Med 2001;7:743.

95. Zheng QH, Fei X, DeGrado TR, et al. Synthesis, biodistribution, and micro-PET imaging of a potential cancer biomarker carbon-11 labeled MMP inhibitor(2R)-2-4-(6fluorohex-1-ynyl)phenyl]sulfonylamino]-3-methylbutyric acid $\left[{ }^{11} \mathrm{C}\right]$ methyl ester. Nucl Med Biol 2003;30:753.

96. Kulasegaram R, Giersing B, Page CJ, et al. In vivo evaluation of ${ }^{111}$ In-DTPA-N-TIMP-2 in Kaposi sarcoma associated with HIV infection. Eur J Nucl Med 2001;28:756.

97. Koivunen E, Arap W, Valtanen $\mathrm{H}$, et al. Tumor targeting with a selective gelatinase inhibitor. Nat Biotechnol 1999; 17:768.

98. Sprague JE, Li WP, Liang K, et al. In vitro and in vivo investigation of matrix metalloproteinase expression in metastatic tumor models. Nucl Med Biol 2006;33:227.

99. Wagner S, Breyholz HJ, Faust A, et al. Molecular imaging of matrix metalloproteinases in vivo using small molecule inhibitors for SPECT and PET [review]. Curr Med Chem 2006;13:2819.

100. MacPherson LJ, Bayburt EK, Capparelli MP, et al. Discovery of CGS 27023A, a non-peptidic, potent, and orally active stromelysin inhibitor that blocks cartilage degradation in rabbits. I Med Chem 1997;40:2525.

101. Scozzafava A, Supuran CT. Carbonic anhydrase and matrix metalloproteinase inhibitors: Sulfonylated amino acid hydroxamates with MMP inhibitory properties act as efficient inhibitors of CA isozymes I, II, and IV, and N-hydroxysulfonamides inhibit both these zinc enzymes. I Med Chem 2000;43:3677.
102. Kopka K, Breyholz HJ, Wagner S, et al. Synthesis and preliminary biological evaluation of new radioiodinated MMP inhibitors for imaging MMP activity in vivo. Nucl Med Biol 2004;31:257.

103. Schäfers M, Riemann B, Kopka K, et al. Scintigraphic imaging of matrix metalloproteinase activity in the arterial wall in vivo. Circulation 2004;109:2554.

104. Zheng QH, Hutchins, GD, Mock BH, et al. MMP inhibitor radiotracer $\left[{ }^{11} \mathrm{C}\right]$ Methyl-CGS 27023A: A new PET breast cancer imaging agent. J Labelled Compd Radiopharm 2001; 44:S104.

105. Fei X, Zheng QH, Hutchins GD, et al. Synthesis of MMP inhibitor radiotracers $\left[{ }^{11} \mathrm{C}\right]$ methyl-CGS $27023 \mathrm{~A}$ and its analogs, new potential PET breast cancer imaging agents. J Labelled Compd Radiopharm 2002;45:449.

106. Zheng QH, Fei X, Liu X, et al. Synthesis and preliminary biological evaluation of MMP inhibitor radiotracers $\left[{ }^{11} \mathrm{C}\right]$ methyl-halo-CGS 27023A analogs, new potential PET breast cancer imaging agents. Nucl Med Biol 2002;29:761.

107. Fei $X$, Zheng QH, Liu X, et al. Synthesis of MMP inhibitor radiotracer $\left[{ }^{11} \mathrm{C}\right] \mathrm{CGS} 25966$, a new potential pet tumor imaging agent. J Labelled Compd Radiopharm 2003; 46:343.

108. Zheng QH, Fei X, Liu X, et al. Comparative studies of potential cancer biomarkers carbon-11 labeled MMP inhibitors (S)-2-(4'-[11C]methoxybiphenyl-4-sulfonylamino)3-methylbutyric acid and N-hydroxy-(R)-2-(4'-[11C] methoxyphenyl)sulfonyl]benzylamino]-3-methylbutanamide. Nucl Med Biol 2004;31:77.

109. Chengazi VU, Feneley MR, Ellison D, et al. Imaging prostate cancer with technetium-99m-7E11-C5.3 (CYT-351). J Nucl Med 1997;38:675.

110. Chang SS, O'Keefe DS, Bacich DJ, et al. Prostate-specific membrane antigen is produced in tumor-associated neovasculature. Clin Cancer Res 1999;5:2674.

111. Chang SS, Reuter VE, Heston WD, et al. Five different antiprostate-specific membrane antigen (PSMA) antibodies confirm PSMA expression in tumor-associated neovasculature. Cancer Res 1999;59:3192.

112. Morris MJ, Divgi CR, Pandit-Taskar N, et al. Pilot trial of unlabeled and indium-111-labeled anti-prostate-specific membrane antigen antibody J591 for castrate metastatic prostate cancer. Clin Cancer Res 2005;11:7454.

113. Morris MJ, Pandit-Taskar N, Divgi CR, et al. Phase I evaluation of J591 as a vascular targeting agent in progressive solid tumors. Clin Cancer Res 2007;13:2707.

114. Foss CA, Mease RC, Fan H, et al. Radiolabeled smallmolecule ligands for prostate-specific membrane antigen: in vivo imaging in experimental models of prostate cancer. Clin Cancer Res 2005;11:4022.

115. Mease RC, Dusich CL, Foss CA, et al. N-[N-[(S)-1,3Dicarboxypropyl]carbamoyl]-4-[ $\left.{ }^{18} \mathrm{~F}\right]$ fluorobenzyl-L-cysteine, $\left[{ }^{18}\right.$ F]DCFBC: A new imaging probe for prostate cancer. $\underline{\text { Clin }}$ Cancer Res 2008;14:3036.

116. Castellani P, Viale G, Dorcaratto A, et al. The fibronectin isoform containing the ED-B oncofetal domain: A marker of angiogenesis. Int J Cancer 1994;59:612.

117. Neri D, Carnemolla B, Nissim A, et al. Targeting by affinitymatured recombinant antibody fragments of an angiogenesisassociated fibronectin isoform. Nat Biotechnol 1997;15: 1271.

118. Viti F, Nilsson F, Demartis S, et al. Design and use of phage display libraries for the selection of antibodies and enzymes. Meth Enzymol 2000;326:480. 
119. Pini A, Viti F, Santucci A, et al. Design and use of a phage display library. Human antibodies with subnanomolar affinity against a marker of angiogenesis eluted from a twodimensional gel. J Biol Chem 1998;273:21769.

120. Demartis S, Tarli L, Borsi L, et al. Selective targeting of tumour neovasculature by a radiohalogenated human antibody fragment specific for the ED-B domain of fibronectin Eur J Nucl Med 2001;28:534.

121. Santimaria M, Moscatelli G, Viale GL, et al. Immunoscintigraphic detection of the ED-B domain of fibronectin, a marker of angiogenesis, in patients with cancer. $\underline{\text { Clin }}$ Cancer Res 2003;9:571.

122. Berndorff D, Borkowski S, Moosmayer D, et al. Imaging of tumor angiogenesis using ${ }^{99 \mathrm{~m}} \mathrm{Tc}$-labeled human recombinant anti-ED-B fibronectin antibody fragments. J Nucl Med 2006;47:1707.

123. Rossin R, Berndorff D, Friebe M, et al. Small-animal PET of tumor angiogenesis using a (76)Br-labeled human recombinant antibody fragment to the ED-B domain of fibronectin. J Nucl Med 2007;48:1172.

124. Carnemolla B, Castellani P, Ponassi M, et al. Identification of a glioblastoma-associated tenascin-C isoform by a highaffinity recombinant antibody. Am J Pathol 1999;154:1345.

125. Silacci M, Brack SS, Spath N, et al. Human monoclonal antibodies to domain $\mathrm{C}$ of tenascin- $\mathrm{C}$ selectively target solid tumors in vivo. Prot Eng Des Sel 2006;19:471.
126. Huminiecki L, Gorn M, Suchting S, et al. Magic roundabout is a new member of the roundabout receptor family that is endothelial specific and expressed at sites of active angiogenesis. Genomics 2002;79:547.

127. Andrews W, Barber M, Hernadez-Miranda LR, et al. The role of Slit-Robo signaling in the generation, migration, and morphological differentiation of cortical interneurons. Dev Biol 2008;313:648.

128. Grone J, Doebler O, Loddenkemper C, et al. Robo1/Robo4: Differential expression of angiogenic markers in colorectal cancer. Oncol Rep 2006;15:1437.

129. Seth $\mathrm{P}$, Lin $\mathrm{Y}$, Hanai J, et al. Magic roundabout, a tumor endothelial marker: Expression and signaling. Biochem Biophys Res Commun 2005;332:533.

130. Legg JA, Herbert JM, Clissold P, et al. Slits and roundabouts in cancer, tumour angiogenesis, and endothelial cell migration. Angiogenesis 2008;11:13.

131. Jain RK. Normalization of tumor vasculature: An emerging concept in antiangiogenic therapy. Science 2005; 307:58.

132. Hlatky L, Hahnfeldt P, Folkman J. Clinical application of antiangiogenic therapy: Microvessel density, what it does and doesn't tell us. J Natl Cancer Inst 2002;94:883.

133. Hurwitz H, Fehrenbacher L, Novotny W, et al. Bevacizumab plus irinotecan, fluorouracil, and leucovorin for metastatic colorectal cancer. NEJMed 2004;350:2335.

\section{About the Authors}

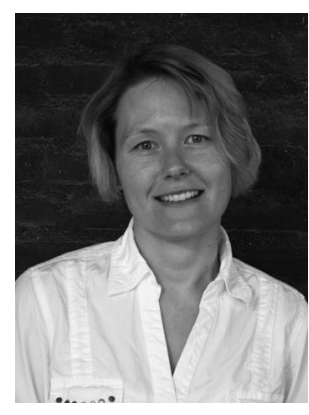

Ingrid Dijkgraaf (Epe, 1979) obtained her MSc in 2002 with specialization in Organic Chemistry at Wageningen University in the Netherlands. From 2002 until 2006, she was a junior investigator at the Department of Medicinal Chemistry and Chemical Biology at Utrecht University and at the Department of Nuclear Medicine at the Radboud University Nijmegen Medical Center. Here, she worked on the synthesis and biologic evaluation of alpha-v-beta-3-binding peptides and peptidomimetics. After obtaining her PhD, she was a postdoctoral fellow (2006-2009) at the Department of Nuclear Medicine at the Technical University of Munich under the supervision of Prof. Dr. Hans-Jürgen Wester. In Munich, she studied the synthesis and in vitro and in vivo evaluation of chemokine receptor-binding ligands. Currently, she works as a postdoc in the group of Prof. Dr. Otto C. Boerman at the Radboud University Nijmegen Medical Center.
Otto C. Boerman (Lochem, 1959) studied Chemistry at the University of Nijmegen in The Netherlands. From 1985 until 1990, he was a junior investigator at the Department of Cell Biology at the University of Nijmegen, where he wrote his thesis, entitled "Development and Application of Monoclonal Antibodies Against Ovarian Carcinoma-Associated Antigens." As a fellow of the Dutch Cancer So-

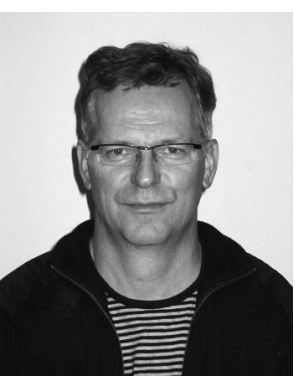
ciety, he worked at the Center for Molecular Medicine and Immunology in Newark, New Jersey (1990-1991) on targeting cancer with radiolabeled monoclonal antibodies. Subsequently, he worked at the Biological Response Modifiers Program of the National Institutes of Health in Frederick, MD (1991-1992) on the in vivo effects of IL-7. When he returned to The Netherlands in 1992, he started his preclinical research group at the Department of Nuclear Medicine of the Radboud University Nijmegen Medical Center. In his group, preclinical studies focus on radionuclide imaging with radiolabeled antibodies and peptides. In 2007, he became a full professor in Radiochemistry at the Radboud University Nijmegen. Prof. Dr. Boerman is a member of the editorial board of The Journal of Nuclear Medicine and The European Journal of Nuclear Medicine and Molecular Imaging. He is a (co-)author of more than 250 peer-reviewed scientific publications. 



\section{This article has been cited by:}

1. Yin Zhang, Hao Hong, Jonathan W. Engle, Yunan Yang, Charles P. Theuer, Todd E. Barnhart, Weibo Cai. 2012. Positron Emission Tomography and Optical Imaging of Tumor CD105 Expression with a Dual-Labeled Monoclonal Antibody. Molecular Pharmaceutics 120131124423004. [CrossRef]

2. Alexander M. Szabo, Nicholas R. Howell, Paul Pellegrini, Ivan Greguric, Andrew Katsifis. 2012. Development and validation of competition binding assays for affinity to the extracellular matrix receptors, \#v\#3 and \#IIb\#3 integrin. Analytical Biochemistry . [CrossRef]

3. Ute Mühlhausen, Dorde Komljenovic, Maren Bretschi, Karin Leotta, Michael Eisenhut, Wolfhard Semmler, Tobias Bäuerle. 2011. A novel PET tracer for the imaging of \#v\#3 and \#v\#5 integrins in experimental breast cancer bone metastases. Contrast Media \& Molecular Imaging 6:6, 413-420. [CrossRef]

4. Hao Hong, Gregory W. Severin, Yunan Yang, Jonathan W. Engle, Yin Zhang, Todd E. Barnhart, Glenn Liu, Bryan R. Leigh, Robert J. Nickles, Weibo Cai. 2011. Positron emission tomography imaging of CD105 expression with 89Zr-Df-TRC105. European Journal of Nuclear Medicine and Molecular Imaging . [CrossRef]

5. Hao Hong, Yunan Yang, Yin Zhang, Jonathan W. Engle, Todd E. Barnhart, Robert J. Nickles, Bryan R. Leigh, Weibo Cai. 2011. Positron emission tomography imaging of CD105 expression during tumor angiogenesis. European Journal of Nuclear Medicine and Molecular Imaging 38:7, 1335-1343. [CrossRef]

6. Keith M Wilcoxen, Jacob Hesterman, Kelly Davis Orcutt, Jack Hoppin. 2011. Intersectional innovation in biomarker development for patient-centric medicine. Personalized Medicine 8:4, 469-481. [CrossRef]

7. Brian R. Blank, Pinar Alayoglu, William Engen, Joseph K. Choi, Clifford E. Berkman, Marc O. Anderson. 2011. NSubstituted Glutamyl Sulfonamides as Inhibitors of Glutamate Carboxypeptidase II (GCP2). Chemical Biology \& Drug Design 77:4, 241-247. [CrossRef]

8. Carola Heneweer, Jan Grimm. 2011. Clinical applications in molecular imaging. Pediatric Radiology 41:2, 199-207. [CrossRef]

9. Nirupama Deshpande, Marybeth A. Pysz, Jürgen K. Willmann. 2010. Molecular ultrasound assessment of tumor angiogenesis. Angiogenesis 13:2, 175-188. [CrossRef]

10. Tobias D. Wheeler, Dexing Zeng, Amit V. Desai, Birce Önal, David E. Reichert, Paul J. A. Kenis. 2010. Microfluidic labeling of biomolecules with radiometals for use in nuclear medicine. Lab on a Chip 10:24, 3387. [CrossRef] 